\title{
GEOGRAPHICAL VARIATION IN SEROLOGICAL TYPES OF URINARY ESCHERICHIA COLI
}

\author{
R. N. Grüneberg and K. A. Bettelheim* \\ Department of Bacteriology, University College Hospital, London, and \\ Salmonella Reference Laboratory, Central Public Health Laboratories, London
}

\begin{abstract}
SiNCE the description by Kauffmann (1944) of a scheme of serological analysis of Escherichia coli and its international acceptance by other workers, many reports have been published of the frequency distribution of serotypes of $E$. coli isolated from urinary-tract infections. Although there has been general agreement that a small number of serotypes are responsible for the majority of urinary infections, there has been less unanimity as to which serotypes predominate. One possible explanation for the variation in serotype distribution in different series is that the common $E$. coli flora differs from place to place. If this explanation is correct it should be possible to demonstrate such geographical differences.
\end{abstract}

\section{MATERIALS AND METHODS}

Three hundred and ninety-five strains of Escherichia coli were collected in three centres in north-west London, namely Edgware General Hospital (122 strains), the Central Public Health Laboratories, Colindale Avenue (155 strains), and the Whittington General Hospital, Archway (118 strains). Geographically, Colindale is situated between the other two centres, being $1 \frac{1}{2}$ miles $(2 \cdot 4 \mathrm{~km})$ from Edgware and $5 \frac{1}{4}$ miles $(8 \cdot 4 \mathrm{~km})$ from Archway.

All strains were collected from patients with acute symptomatic urinary infection seen in general practice. The patients came from small regions surrounding the three centres. There was a slight overlap between the Edgware and Colindale "catchment areas", but none between either of these areas and the Archway area. All three areas contain densely populated urban communities. The populations of Edgware and Colindale are composed predominantly of long-established households of social classes II and III, that of the Archway belongs to social classes III and IV, and includes a large immigrant element. As far as is known, all the patients had become infected in the home, not in a hospital environment.

In the Edgware series, clean specimens of urine were collected in the laboratory from patients referred by their general practitioners to a special clinic for the investigation of urinary infection. In both the Colindale and Archway series, the strains were derived from clean urine samples sent to the routine diagnostic laboratories by local general practitioners. The specimens from Colindale and Edgware were collected during the period from Feb. 1965 to Sept. 1966, the specimens from Archway between Oct. 1966 and July 1967. In all three centres, surface viable counts were performed and the sole criterion of urinary infection was the isolation of an organism in pure growth in numbers exceeding 100,000 per $\mathrm{ml}$ urine. $E$. coli was identified by standard bacteriological methods. In all three laboratories the $O$ (somatic) antigenic group of the strains of $E$. coli was determined in tests made by standard methods with the same full range of $147 \mathrm{O}$-antisera (Ewing, 1956).

Received 20 Aug. 1968; accepted 30 Oct. 1968.

* Present address: Department of Biochemistry, Imperial College, London, S.W.7.

J. MED. MICROBIOL.-voL. 2 (1969) 


\section{RESULTS}

The O-grouping results for the 395 urinary strains of Escherichia coli from the three centres are shown in table I.

\section{TABLE I}

O-group distribution of strains of Escherichia coli isolated from cases of urinary infection in the Edgware, Colindale and Archway centres

\begin{tabular}{|c|c|c|c|c|c|}
\hline \multirow{2}{*}{\multicolumn{2}{|c|}{ O-group }} & \multicolumn{4}{|c|}{ Number of strains in O-group in } \\
\hline & & $\begin{array}{l}\text { Edgware } \\
\text { series }\end{array}$ & $\begin{array}{l}\text { Colindale } \\
\text { series }\end{array}$ & $\begin{array}{l}\text { Archway } \\
\text { series }\end{array}$ & $\begin{array}{l}\text { all three } \\
\text { series }\end{array}$ \\
\hline & $\begin{array}{l}\text { O6 } \\
\text { O75 } \\
\text { O4 } \\
\text { O2 } \\
\text { O7 }\end{array}$ & $\begin{array}{r}17 \\
21 \\
8 \\
9 \\
7\end{array}$ & $\begin{array}{r}24 \\
12 \\
10 \\
9 \\
7\end{array}$ & $\begin{array}{r}22 \\
19 \\
7 \\
5 \\
8\end{array}$ & $\begin{array}{l}63 \\
52 \\
25 \\
23 \\
22\end{array}$ \\
\hline & $\begin{array}{l}\text { O1 (O31) } \\
\text { O18ac } \\
\text { O11 } \\
\text { O22 } \\
\text { O12 }\end{array}$ & $\begin{array}{l}6 \\
5 \\
5 \\
1 \\
1\end{array}$ & $\begin{array}{l}7 \\
7 \\
4 \\
5 \\
0\end{array}$ & $\begin{array}{l}8 \\
6 \\
0 \\
2 \\
4\end{array}$ & $\begin{array}{r}21 \\
18 \\
9 \\
8 \\
5\end{array}$ \\
\hline & $\begin{array}{l}\text { O123 } \\
\text { O17 } \\
\text { O25 } \\
\text { O39 } \\
\text { O8 }\end{array}$ & $\begin{array}{l}2 \\
3 \\
2 \\
4 \\
0\end{array}$ & $\begin{array}{l}1 \\
1 \\
0 \\
0 \\
2\end{array}$ & $\begin{array}{l}2 \\
0 \\
2 \\
0 \\
1\end{array}$ & $\begin{array}{l}5 \\
4 \\
4 \\
4 \\
3\end{array}$ \\
\hline & $\begin{array}{l}\text { O48 } \\
\text { O83 } \\
\text { O145 } \\
\text { O3 } \\
\text { O5 }\end{array}$ & $\begin{array}{l}1 \\
1 \\
1 \\
0 \\
0\end{array}$ & $\begin{array}{l}2 \\
2 \\
1 \\
1 \\
2\end{array}$ & $\begin{array}{l}0 \\
0 \\
1 \\
1 \\
0\end{array}$ & $\begin{array}{l}3 \\
3 \\
3 \\
2 \\
2\end{array}$ \\
\hline & $\begin{array}{l}\text { O27 } \\
\text { O46 } \\
\text { O53 } \\
\text { O69 } \\
\text { O76 }\end{array}$ & $\begin{array}{l}0 \\
1 \\
0 \\
0 \\
0\end{array}$ & $\begin{array}{l}2 \\
1 \\
0 \\
2 \\
1\end{array}$ & $\begin{array}{l}0 \\
0 \\
2 \\
0 \\
1\end{array}$ & $\begin{array}{l}2 \\
2 \\
2 \\
2 \\
2\end{array}$ \\
\hline & $\begin{array}{l}\text { O86 } \\
\text { O147 }\end{array}$ & $\begin{array}{l}1 \\
0\end{array}$ & $\begin{array}{l}1 \\
2\end{array}$ & $\begin{array}{l}0 \\
0\end{array}$ & $\begin{array}{l}2 \\
2\end{array}$ \\
\hline Other groups* & ; & 8 & 17 & 6 & 31 \\
\hline Untypable sm & nooth strains & 13 & 24 & 8 & 45 \\
\hline All smooth st & trains . & 117 & 147 & 105 & 369 \\
\hline Rough strains & . & 5 & 8 & 13 & 26 \\
\hline All strains & . & 122 & 155 & 118 & 395 \\
\hline
\end{tabular}

* Thirty-one other groups, of which only one strain was found in the three series, were 09,010 , O13, O14, O15, O16, O19, O20, O21, O30, O33, O36, O42, O44, O52, O55, O57, O71, O73, O79, 081, O89, O91, O106, O113, O115, O125, O131, O134, O135 and O138. 


\section{Discussion}

Many of the reports from the extensive literature on the isolation of different serotypes of Escherichia coli from the urine of patients with urinary-tract infections are not easily analysed because they give only the order of frequency of occurrence of particular serotypes, e.g., Ujváry (1957-58), or because they give information about only a few serotypes, e.g., Sjösted (1946), Grönroos, Mustakallio and Virtanen (1955), Kubinyiné-Schwanner and Hamar (1955, cited from Leppänen, 1958), and Guinée (1963). The more detailed findings

TABLE II

$O$-groups of strains of $E$. coli isolated from urinary-tract infections in eleven series reported by previous authors

\begin{tabular}{|c|c|c|c|c|c|c|c|c|c|c|c|c|}
\hline \multirow{2}{*}{ Authors of series } & \multicolumn{10}{|c|}{ Number of strains in O-groups } & \multirow{2}{*}{$\begin{array}{c}\text { Other } \\
\text { O-groups }\end{array}$} & \multirow{2}{*}{$\underset{\text { O-groups }}{\text { All }}$} \\
\hline & O1 & $\mathrm{O} 2$ & O4 & O6 & O7 & O9 & O11 & 018 & O39 & O75 & & \\
\hline 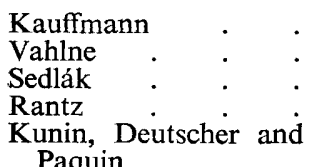 & $\begin{array}{r}4 \\
17 \\
3 \\
7 \\
12\end{array}$ & $\begin{array}{r}3 \\
17 \\
7 \\
6 \\
7\end{array}$ & $\begin{array}{r}2 \\
18 \\
47 \\
20 \\
9\end{array}$ & $\begin{array}{r}2 \\
1 \\
12 \\
24 \\
16\end{array}$ & $\begin{array}{r}1 \\
13 \\
1 \\
5 \\
16\end{array}$ & $\begin{array}{l}1 \\
5 \\
1 \\
3 \\
0\end{array}$ & $\begin{array}{l}0 \\
0 \\
0 \\
0 \\
2\end{array}$ & $\begin{array}{r}0 \\
10 \\
1 \\
3 \\
0\end{array}$ & $\begin{array}{l}- \\
\overline{0} \\
0 \\
0\end{array}$ & $\begin{array}{r}- \\
\overline{8} \\
21 \\
12\end{array}$ & $\begin{array}{l}13 \\
19 \\
90 \\
67 \\
97\end{array}$ & $\begin{array}{r}26 \\
100 \\
170 \\
156 \\
171\end{array}$ \\
\hline $\begin{array}{l}\text { Vosti et al. } \\
\text { Andersen et al. } \\
\text { McGeachie } \\
\text { Maiztegui and Kass } \\
\text { Neter } \text { et al. } \\
\text { Pryles and Glagovsky: }\end{array}$ & $\begin{array}{r}11 \\
10 \\
32 \\
7 \\
8 \\
26\end{array}$ & $\begin{array}{r}2 \\
13 \\
19 \\
0 \\
1 \\
4\end{array}$ & $\begin{array}{r}33 \\
3 \\
38 \\
9 \\
5 \\
25\end{array}$ & $\begin{array}{r}39 \\
1 \\
35 \\
28 \\
13 \\
37\end{array}$ & $\begin{array}{r}8 \\
5 \\
6 \\
7 \\
5 \\
22\end{array}$ & $\begin{array}{l}0 \\
1 \\
1 \\
2 \\
1 \\
3\end{array}$ & $\begin{array}{l}4 \\
0 \\
4 \\
6 \\
0 \\
3\end{array}$ & $\begin{array}{r}6 \\
6 \\
21 \\
0 \\
1 \\
3\end{array}$ & $\begin{array}{l}1 \\
0 \\
4 \\
0 \\
0 \\
0\end{array}$ & $\begin{array}{r}10 \\
2 \\
17 \\
19 \\
11 \\
34\end{array}$ & $\begin{array}{r}112 \\
14 \\
139 \\
85 \\
55 \\
131\end{array}$ & $\begin{array}{r}226 \\
55 \\
316 \\
163 \\
100 \\
288\end{array}$ \\
\hline All series . & 137 & 79 & 209 & 208 & 89 & 18 & 19 & 51 & 5 & 134 & 822 & 1771 \\
\hline
\end{tabular}

of other workers on the most commonly occurring O-groups are summarised in table II.

It can be seen that the ten O-groups listed in table II are responsible for between 43 and 81 per cent. of the smooth $E$. coli strains in these series. There are considerable differences in incidence of the various O-types. Six of the series come from America: Rantz (1962), Kunin, Deutscher and Paquin (1964), Vosti et al. (1964), Maiztegui and Kass (1965), Neter et al. (1965) and Pryles and Glagovsky (1965), and five come from Europe: Kauffmann (1944), Vahlne (1945), Sedlák (1955), Andersen et al. (1965) and McGeachie (1965). A comparison of the frequency of occurrence of some of the more common O-serotypes of E. coli in the six American and five European studies is presented in table III.

Table III shows that in the case of at least six O-groups, namely O1, O2, $\mathrm{O} 4, \mathrm{O}, \mathrm{O} 18$ and $\mathrm{O} 75$, there is a statistically significant difference in the frequency of occurrence of strains between the American and the European series. That is to say, geographical differences in urinary $E$. coli O-group distribution have been demonstrated on a continental scale. 
Table IV compares the O-group distributions observed in the present study in the three centres in north-west London. Because of the relatively small numbers of strains, only the most commonly occurring O-groups are listed.

TABLE III

Comparison of the frequency of certain serotypes of E. coli in urinary-tract infections in the American and European series

\begin{tabular}{c|c|c|c}
\hline \multirow{2}{*}{ O-group } & \multicolumn{2}{|c|}{ Percentage of strains in O-group in } & \multicolumn{1}{c}{$\begin{array}{c}\text { Value of } \mathbf{P} \text { for } \\
\text { difference (from } \chi^{2} \text { test) }\end{array}$} \\
\cline { 2 - 3 } & American series & European series & \\
\hline & & & \\
O1 & $6 \cdot 3$ & $9 \cdot 9$ & $<0.01$ \\
O2 & $1 \cdot 8$ & $8 \cdot 8$ & $<0.001$ \\
O4 & $6 \cdot 3$ & $16 \cdot 2$ & $<0.001$ \\
O6 & $14 \cdot 2$ & $7 \cdot 6$ & $<0.001$ \\
O18 & $1 \cdot 2$ & $5 \cdot 7$ & $<0.001$ \\
O75 & $9 \cdot 1$ & $4 \cdot 1$ & $<0.001$ \\
\hline
\end{tabular}

Nevertheless, it is clear that statistically significant differences in the incidence of strains of group O75 in the three series have been demonstrated $(\mathrm{P}<0.05)$ and also a significant difference in the incidence of smooth untypable strains

TABLE IV

Comparison of the frequency of certain serotypes of $E$. coli in domiciliary urinary infections in three areas in north-west London

\begin{tabular}{c|c|c|c}
\hline \multirow{2}{*}{ O-group } & \multicolumn{3}{|c}{ Percentage of strains in O-group in } \\
\cline { 2 - 4 } & $\begin{array}{c}\text { Edgware series } \\
\text { (117 strains) }\end{array}$ & $\begin{array}{c}\text { Colindale series } \\
\text { (147 strains) }\end{array}$ & $\begin{array}{c}\text { Archway series } \\
\text { (105 strains) }\end{array}$ \\
\hline & $7 \cdot 7$ & $6 \cdot 1$ & $4 \cdot 8$ \\
O2 & $6 \cdot 8$ & $6 \cdot 8$ & $6 \cdot 7$ \\
O4 & $14 \cdot 5$ & $16 \cdot 3$ & $21 \cdot 0$ \\
O6 & $4 \cdot 3$ & $4 \cdot 7$ & 0 \\
O11 & $4 \cdot 3$ & $8 \cdot 2^{*}$ & $18 \cdot 1$ \\
O15 & 17.9 & $19 \cdot 9 \dagger$ & $7 \cdot 6$ \\
\hline
\end{tabular}

* Values of $\mathbf{P}$ for differences from results in Edgware and Archway series is $<0.05$.

$\uparrow$ Value of $\mathbf{P}$ for difference from result in Archway series is $<0.05$.

between the Colindale and Archway series $(\mathrm{P}<0.05)$. It is also of interest to note that with the O-groups of $E$. coli that do not show statistically significant differences between the different series, the percentage incidence of an O-group in Colindale lies between the percentage incidences for Edgware and Archway. Geographically, Colindale is situated between the other two centres, being $1 \frac{1}{2}$ miles $(2.4 \mathrm{~km})$ from Edgware and $5 \frac{1}{4}$ miles $(8.4 \mathrm{~km})$ from Archway. It seems, therefore, that the O-group distribution of strains of $E$. coli from urinary-tract 
infections may differ not only between different continents but even between areas separated by only a few miles.

How reliable are these findings? It must be recognised that the comparison between European and American results may lead to wrong conclusions for at least three reasons. First, the patients have been selected from different population groups, which may or may not include patients with symptomatic acute infections in general practice, antenatal-clinic patients, and hospital patients. Since differences in O-group distribution between such groups of patients have been demonstrated by Kennedy, Plorde and Petersdorf (1965) and Grüneberg, Leigh and Brumfitt (1968), comparisons of the incidence of the $O$-groups of urinary strains of $E$. coli isolated from mixed sources may be misleading. Second, the methods used and the degree of experience of the workers in the different studies are probably not similar. Third, the degree of serological differentiation achieved will vary with the number of different $\mathrm{O}$-antisera used. The number of different $\mathrm{O}$-antisera used in the studies reviewed ranges from 25 to 145 . Nonetheless, it is probable that these drawbacks will apply fairly equally to both American and European reports, and it seems reasonable to accept with reservations the major findings of the over-all comparison, that true differences exist in the type distribution between the two continents. These criticisms do not apply to our own comparisons between $E$. coli strains isolated in three centres in north-west London. All the strains were isolated according to the same criteria from domiciliary patients with acute, symptomatic urinary infections. The serological methods of identification used were the same for all strains.

It is assumed that the geographical differences demonstrated in the distribution of O-groups of the strains of $E$. coli isolated from infected urines reflect differences in the faecal $E$. coli flora in the various localities. In spite of observed variation in frequency distribution of the common serotypes, both from continent to continent and from locality to locality, it should be emphasised that the present series confirms the predominance of O-groups $\mathrm{O} 2, \mathrm{O} 4, \mathrm{O} 6$, $\mathrm{O} 18$ and $\mathrm{O} 75$, regardless of locality.

\section{SUMMARY}

Comparison of the distributions of the O-groups of strains of Escherichia coli isolated from infected urines in eleven previous studies has shown that there are statistically significant differences in the frequency distributions of certain O-groups between the findings in America and those in Europe. It is considered that in spite of differences in the methods of patient selection, the bacteriological methods and the levels of serological refinement used in the different investigations, these apparent intercontinental differences in O-group distribution are probably real.

In a study of the O-groups of the E. coli strains isolated from the urines of domiciliary patients with symptomatic infection of the urinary tract in three centres in north-west London, we have confirmed the preponderance of O-groups $\mathrm{O} 2, \mathrm{O} 4, \mathrm{O} 6, \mathrm{O} 18$ and $\mathrm{O} 75$ in all three localities. Nevertheless, the 
frequency of occurrence of certain O-groups differed significantly in the three localities, indicating that geographical differences occur not only between different continents but also between regions separated by only a few miles. This geographical variation in the O-group distribution of urinary strains of $E$. coli is presumably a reflection of a similar geographical variation in the O-groups of $E$. coli strains in the faecal flora.

We wish to thank Mr D. P. Woodroof for his capable technical assistance and Dr Joan Taylor, Dr W. Brumfitt and Dr A. F. Mohun for advice, help and encouragement, and the North-Western Metropolitan Hospital Board for research funds.

\section{REFERENCES}

ANDERSEN, H. J., HANSON, L. A., 1965. Acta paediat. scand., 54, 247. LiNCOLN, K., ØrSKOV, IDA, ØrSKOV, F., AND WINBERG, J.

EWING, W. H.

Grönroos, J. A., Mustakallio, E., AND 1955. VirTANEN, S.

GrüneberG, R. N., LeIGH, D. A., AND 1968. BRUMFITT, W.

GuinÉE, P. A. M. . . . . . 1963.

1963. Thesis, Univ. Utrecht.

• • • . . 1944. Acta path. microbiol. scand., 21, 20.

Kennedy, R. P., Plorde, J. J., ANd 1965. J. Clin. Invest., 44, 193. PETERSDORF, R. G.

Kunin, C. M., Deutscher, R., AND 1964. Medicine, Baltimore, 43, 91. PAQUin, A., JR

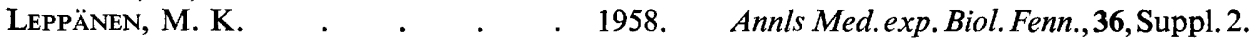

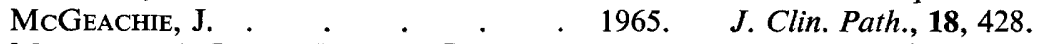

MaizTegui, J. I., AND Kass, E. H. - 1965. In Progress in pyelonephritis, ed. by

Neter, E., Steinhart, J., Calcagno, 1965. Ibid., p. 129. P. L., AND RUBIN, M. I.

Pryles, C. V., and Glagovsky, Ann - 1965. Pediatrics, 36, 219.

RANTZ, L. A. - . . . . . 1962. Archs Intern. Med., 109, 37.

SEdlák, J. . . . . . . . 1955. Acta Univ. Carol., Suppl., 5, 22.

SJÖSTED, S. $\quad$. $\quad$. $\quad$. $\quad$. 1946. Acta path. microbiol. scand., Suppl. 3.

UJVÁRY, G. 1957-58. Zentbl. Bact., Abt. I, Orig., 170, 394.

VAHLNE, G. . . . . . . 1945. Acta path. microbiol. scand., Suppl. 62.

Vosti, K. L., Goldberg, L. M., Monto, 1964. J. Clin. Invest., 43, 2377. A. S., AND Rantz, L. A. 